\title{
Measurements of ozone and its precursors in Beijing during summertime: impact of urban plumes on ozone pollution in downwind rural areas
}

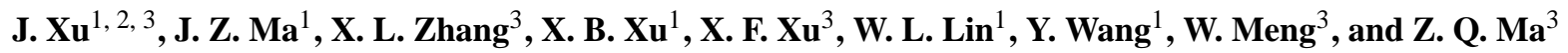 \\ ${ }^{1}$ Chinese Academy of Meteorological Sciences, Beijing 100081, China \\ ${ }^{2}$ Graduate University of Chinese Academy of Sciences, Beijing 100049, China \\ ${ }^{3}$ Institute of Urban Meteorology, China Meteorological Administration, Beijing 100089, China
}

Received: 23 May 2011 - Published in Atmos. Chem. Phys. Discuss.: 21 June 2011

Revised: 7 November 2011 - Accepted: 16 November 2011 - Published: 7 December 2011

\begin{abstract}
Sea-land and mount-valley circulations are the dominant mesoscale synoptic systems affecting the Beijing area during summertime. Under the influence of these two circulations, the prevailing wind is southwesterly from afternoon to midnight, and then changes to northeasterly till forenoon. In this study, surface ozone $\left(\mathrm{O}_{3}\right)$, carbon monoxide $(\mathrm{CO})$, nitric oxide (NO), nitrogen dioxide $\left(\mathrm{NO}_{2}\right)$, nitrogen oxide $\left(\mathrm{NO}_{\mathrm{x}}\right)$ and non-methane hydrocarbons (NMHCs) were measured at four sites located along the route of prevailing wind, including two upwind urban sites (Fengtai "FT" and Baolian "BL"), an upwind suburban site (Shunyi "SY") and a downwind rural site (Shangdianzi "SDZ") during 20 June-16 September 2007. The purpose is to improve our understanding of ozone photochemistry in urban and rural areas of Beijing and the influence of urban plumes on ozone pollution in downwind rural areas. It is found that ozone pollution was synchronism in the urban and rural areas of Beijing, coinciding with the regional-scale synoptic processes. Due to the high traffic density and local emissions, the average levels of reactive gases $\mathrm{NO}_{\mathrm{x}}$ and NMHCs at the non-rural sites were much higher than those at SDZ. The level of long-lived gas $\mathrm{CO}$ at SDZ was comparable to, though slightly lower than, at the urban sites. We estimate the photochemical reactivity $\left(L_{\mathrm{OH}}\right)$ and the ozone formation potential (OFP) in the urban (BL) and rural (SDZ) areas using measured $\mathrm{CO}$ and NMHCs. The $\mathrm{OH}$ loss rate coefficient $\left(L_{\mathrm{OH}}\right)$ by total NMHCs at the BL and SDZ sites are estimated to be $50.7 \mathrm{~s}^{-1}$
\end{abstract}

Correspondence to: J. Z. Ma

(mjz@cams.cma.gov.cn) and $15.8 \mathrm{~s}^{-1}$, respectively. While alkenes make a major contribution to the $L_{\mathrm{OH}}$, aromatics dominate OFP at both urban and rural sites. With respect to the individual species, $\mathrm{CO}$ has the largest ozone formation potential at the rural site, and at the urban site aromatic species are the leading contributors. While the $\mathrm{O}_{3}$ diurnal variations at the four sites are typical for polluted areas, the ozone peak values are found to lag behind one site after another along the route of prevailing wind from SW to NE. Intersection analyses of trace gases reveal that polluted air masses arriving at SDZ were more aged with both higher $\mathrm{O}_{3}$ and $\mathrm{O}_{\mathrm{x}}$ concentrations than those at $\mathrm{BL}$. The results indicate that urban plume can transport not only $\mathrm{O}_{3}$ but its precursors, the latter leading more photochemical $\mathrm{O}_{3}$ production when being mixed with background atmosphere in the downwind rural area.

\section{Introduction}

Beijing is one of the world's largest cities with population over 15 million and an area of $16808 \mathrm{~km}^{2}$. Accompanying the rapid growth in traffic, photochemical pollution in Beijing has become more serious in recent years (Hao and Wang, 2005; Shao et al., 2006; Wang et al.,2006). For example, the ambient air quality standard for ozone has frequently been exceeded, with the peak hourly averaged concentration of $286 \mathrm{ppbv}$ recorded (Wang et al., 2006). Beijing is the center of an urban agglomeration in North China. Compared to the other two city cluster regions in China, i.e. the Yangtze River delta (Cheung and Wang, 2001; Chan et al., 2003; Geng et al., 2007) and the Pearl River delta (So and Wang, 2003;

Published by Copernicus Publications on behalf of the European Geosciences Union. 
Wang and Kwok, 2003; Ding et al., 2004; Lam et al., 2005; Zhang et al., 2008b), research on photochemical pollution in Beijing was started scarcely.

Previous studies focused mainly on the spatial and temporal variations of surface ozone and its precursors (Shao et al., 2009; Tang et al., 2009; Wang et al., 2010). Countable reports on the photochemical processes suggested that the ozone production processes and formation regimes are complicated and non-uniformly distributed within the Beijing area. For example, Lu et al. (2010) indicated that both $\mathrm{NO}_{\mathrm{x}}$ and VOCs (volatile organic compounds)-sensitive chemistry exist at the urban and suburban sites with ozone production, $P\left(\mathrm{O}_{3}\right)$, varying from nearly zero to 120 and $50 \mathrm{ppbv} \mathrm{h}^{-1}$, respectively. It has been indicated that the $P\left(\mathrm{O}_{3}\right)$ in the urban area is more VOCs-sensitive with the ozone production efficiency (OPE) varying from 1.5 to 6.0 near the high $\mathrm{NO}_{\mathrm{x}}$ emission sources (An, 2006), and from 3.9 to 7.9 with low $\mathrm{NO}_{\mathrm{x}}$ emissions (Chou et al., 2009). Model results suggest that the current high surface ozone is strongly stimulated by VOCs emissions in the urban area of Beijing, indicating that the current ozone formation in Beijing is under $\mathrm{NO}_{\mathrm{x}}$ saturated conditions. $\mathrm{NO}_{\mathrm{x}}$ emissions could have a strong inhibitory effect on ozone formation, even after a $50 \% \mathrm{NO}_{\mathrm{x}}$ emission reduction. A transition of ozone formation was observed from $\mathrm{NO}_{\mathrm{x}}$-saturated to $\mathrm{NO}_{\mathrm{x}}$-limited sensitivity behavior with a $75 \%$ reduction of $\mathrm{NO}_{\mathrm{x}}$ emissions (Tang et al., 2010). Further studies indicated that ozone formation in Beijing is sensitive to VOCs for both urban and rural sites (Shao et al., 2009; Wang et al., 2010), and a reduction in $\mathrm{NO}_{\mathrm{x}}$ would lead to a decrease in ozone at the rural site, but would cause an increase in ozone at the urban site (Shao et al., 2009). In the urban area vehicle activities contribute dominantly to both the VOCs loading and the ozone formation potential, while in the rural area the contribution of traffic is much lower (Yuan et al., 2009). These suggest that it is needed to investigate the ozone-related processes individually in different regions because there is no geographically uniform response to $\mathrm{NO}_{\mathrm{x}}$ and VOCs owing to the intricate emission conditions in the Beijing area.

Previous studies also highlighted the importance of regional transport from the urban to rural area of Beijing as it was found that the highest concentrations of $\mathrm{O}_{3}$ and other trace gases observed at the rural site are mainly due to emissions from the Beijing urban area (Wang et al., 2006). Lin et al. (2008) analyzed ozone and its precursors observed at Shangdianzi (SDZ), a regional atmospheric background station in North China, over the period 2004-2006. The contribution of pollutants from the North China Plain to surface ozone at SDZ was estimated at an average value of $21.8 \mathrm{ppbv}$, mostly from SW of the station. Meng (2008) indicated that the intensive biomass burning in the North China Plain, in combination with the transport of regional pollution by more frequent southwesterly winds, are responsible for the elevated CO concentration during summertime at SDZ. Diurnal variation of $\mathrm{O}_{3}$ with delayed peaking time suggests that the transport of photochemical aged plume is an important source for $\mathrm{O}_{3}$ at SDZ (Lin et al., 2008; Meng et al., 2008). All these studies were carried out based on measurements in the downwind rural areas. Wang et al. (2010) conducted field studies at the three sites that lie roughly on a south-north axis in and outside Beijing before and during the 2008 Olympics. By taking the difference between the maximum $1 \mathrm{~h}$ ozone concentration at the urban site and the ozone value at the same time at the upwind site ( $\sim 50 \mathrm{~km}$ southwest of Beijing), they showed that the regional sources contributed $34-88 \%$ to the peak ozone at the urban site during the selected episodes. They also showed that the ozone (and CO) peak at the downwind site ( $\sim 50 \mathrm{~km}$ north of Beijing) lagged behind that at the urban site in time due to the transport of regional and Beijing plumes to the downwind rural site in the afternoon.

Previous studies have highlighted the importance of pollution transport to the ozone variations in Beijing and its downwind areas. However, what extent these pollution plumes can influence and what changes in chemical characteristics of air masses occur during the transport are still not well understood. In order to further reveal the impact of urban plumes on summertime ozone pollution in the downwind rural area of Beijing, simultaneous measurements of $\mathrm{O}_{3}$ and its precursors (i.e. VOCs, $\mathrm{CO}$ and $\mathrm{NO}_{\mathrm{x}}$ ) were conducted at four sites located along the route of prevailing wind in the region from June to September 2007 (this is the season that $\mathrm{O}_{3}$ episodes are often observed). In this paper, we present the analytical results of these measurement data including the concentrations of individual trace gases and total non-methane hydrocarbons (NMHCs). The photochemical reactivity and ozone formation potential of VOCs species in the urban and rural areas of Beijing are analyzed. Furthermore, diurnal variation patterns of ozone and its precursors at the urban and rural sites are compared under different prevailing wind conditions to investigate the transport effects of urban plume on the downwind area. Finally, we examine the interspecies correlations among $\mathrm{O}_{3}, \mathrm{CO}$ and selected VOCs species to investigate the photochemical age of air masses at the two sites.

\section{Experimental}

\subsection{Meteorological background and monitoring sites}

Beijing municipality is located on the northwestern border of the North China Plain bounded by mountains on the north, east, and west. Many heavily populated industrialized cities are close to Beijing on the southwest and southeast. Sea-land breeze and mountain-valley breeze are the two mesoscale circulations affecting the Beijing area. The mountain-valley breeze may influence the whole plain area, and the influence of sea-land breeze can reach as far as $100 \mathrm{~km}$ approximately into the inland. Under the influence of these two circulations, the prevailing wind is southerly from afternoon to midnight, and then changes to northerly till forenoon. The 

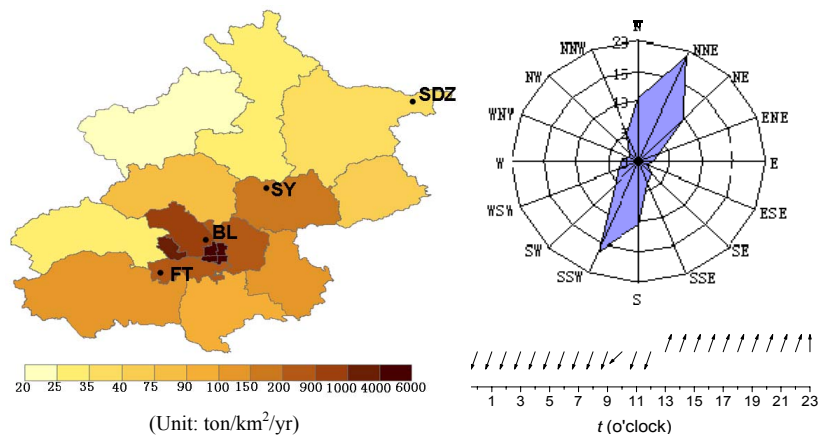

Fig. 1. Sites location and CO emission density (Zhao et al., 2011) (left) and the wind direction rose with the diurnal variation of prevailing wind (right). (FT: FengTai; BL: BaoLian; SY: ShunYi; SDZ: ShangDianZi).

prevailing wind direction rose and the averaged diurnal variation of wind vector are shown in Fig. 1.

Along to the route of prevailing wind, four sites distributed from southwest to northeast in Beijing municipality were selected to observe ozone and its precursors. These include two urban sites (Fengtai "FT") and Baolian "BL"), one suburban site (Shunyi "SY"), and one rural site (SDZ). The FT and SY sites are located in the meteorological observation fields surrounded by low rising vegetation. The BL site is located in the Baolian Sports Park surrounded by residential districts, about $2 \mathrm{~km}$ away from the Third Ring Road. Compared to the urban sites, the SY site is relatively close to the high $\mathrm{NO}_{\mathrm{x}}$ emission sources and located about $5 \mathrm{~km}$ away from the Sixth Ring Road of Beijing. SDZ is one of the regional Global Atmosphere Watch (GAW) stations in China. The station is located in the northern part of the North China Plain, about $100 \mathrm{~km}$ northeast of the Beijing metropolitan center and $55 \mathrm{~km}$ northeast of the Miyun County Town of Beijing, respectively. The station is surrounded by largescale crops and sparsely populated small villages. According to afternoon prevailing wind direction, FT and BL are the upwind urban sites, and SY is the upwind suburban site with respect to the downwind rural site SDZ.

\subsection{Instrumental methods}

Concentrations of ozone and its precursors $\left(\mathrm{CO}, \mathrm{NO}, \mathrm{NO}_{2}\right.$ and $\mathrm{NO}_{\mathrm{x}}$ ) at $\mathrm{BL}$ and FT stations were observed by a set of commercial instruments from Ecotech, Inc., Australia. The instruments include an EC9810 Ozone Analyzer for ozone, an EC9830 Analyzer for CO, and an EC9841 Analyzer for $\mathrm{NO}_{\mathrm{x}}$. Ozone and its precursors at SY and SDZ stations were observed by a set of commercial instruments from Thermo Environmental Instrument, Inc., USA. The instruments include an TE 49C Ozone Analyzer for ozone, an TE 48C Analyzer for $\mathrm{CO}$, and an TE 42CTL $\mathrm{NO}_{\mathrm{x}}$ Analyzer for $\mathrm{NO}_{\mathrm{x}}$. Specifications of the sampling methods and instruments are shown in Table 1. Ambient air samples were drawn through a

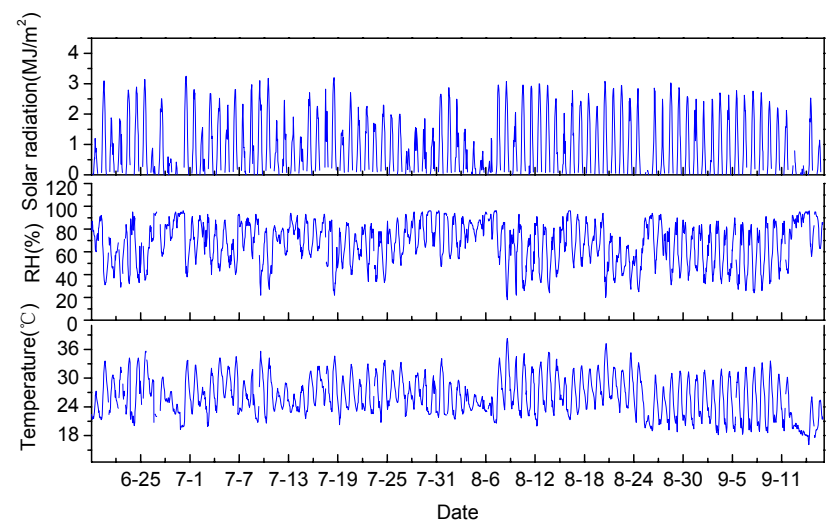

Fig. 2. Time series of hourly mean values of accumulative solar radiation, relative humidity and temperature at BL.

$1.5 \mathrm{~m}$ Teflon tube above the rooftop in both stations. The inlet was installed $3.5 \mathrm{~m}$ above the ground. At BL and FT stations, daily zero/span checks were automatically done using a dynamic gas calibrator (Ecotech GasCal 1000) in combination with a zero air supply (Sabio Model 1001) and a set of standard reference gas mixtures. At SY and SDZ stations, daily zero/span checks were automatically done using a dynamic gas calibrator (TE 146C) in combination with a zero air supply (TE 111) and a set of standard reference gas mixtures. Both mixtures used at the two stations were from the Chemical Metrology and Analytical Science Division, National Institute of Metrology, Beijing, China. Multipoint calibrations were made every 3-6 months. For ozone, the standards are traceable to the Standard Reference Photometer (SRP) maintained by WMO World Calibration Centre in Switzerland (EMPA). The standard gases of $\mathrm{NO}$ and $\mathrm{CO}$ were compared against NIST-traceable standards from Scott Specialty Gases, USA. After the correction of data on the basis of multipoint calibration, hourly averaged data were calculated and are used for further analysis in this study.

During the experiment, 55 species of NMHCs $\left(\mathrm{C}_{2}-\mathrm{C}_{9}\right)$ were measured and identified by a thermal desorption gas chromatographic system (Autosystem XL, Perkin-Elmer) with two capillary columns and FIDs (Wang et al., 2002; Tang et al., 2007) at BL and SDZ. Morning time and afternoon time samples were collected on each Tuesday at 08:00 08:30 LT and 14:00-14:30 LT, respectively. Besides, more samples were collected at 06:00-06:30 LT, 10:00-10:30 LT, 14:00-14:30 LT, 16:00-16:30 LT, and 20:00-20:30 LT on some representative days.

\section{Results and discussion}

\subsection{Time series overview and statistical analysis}

Time series of meteorological parameters and hourly averaged $\mathrm{O}_{3}, \mathrm{NO}_{\mathrm{x}}, \mathrm{CO}$, and NMHCs are shown in Figs. 2 and 
Table 1. Specifications of instruments and sampling methods.

\begin{tabular}{|c|c|c|c|c|c|}
\hline Station & Air & Instrument & Method & $\begin{array}{l}\text { Measurement } \\
\text { range }\end{array}$ & $\begin{array}{l}\text { Detection } \\
\text { limit }\end{array}$ \\
\hline \multirow{2}{*}{ FT } & $\mathrm{O}_{3}$ & EC9810 Ozone Analyzer & Ultraviolet photometric method & $0-20 \mathrm{ppmv}$ & $0.5 \mathrm{ppbv}$ \\
\hline & $\mathrm{NO}_{\mathrm{x}}$ & EC9841 NOx Analyzer & Chemiluminescence & $0-20 \mathrm{ppmv}$ & $0.5 \mathrm{ppbv}$ \\
\hline \multirow{3}{*}{ BL } & $\mathrm{O}_{3}$ & EC9810 Ozone Analyzer & Ultraviolet photometric method & $0-20 \mathrm{ppmv}$ & $0.5 \mathrm{ppbv}$ \\
\hline & $\mathrm{NO}_{\mathrm{x}}$ & EC9841 NO & Chemiluminescence & $0-20 \mathrm{ppmv}$ & $0.5 \mathrm{ppbv}$ \\
\hline & $\mathrm{CO}$ & EC9830 CO Analyzer & Gas filter correlation & 0-200 ppmv & $0.05 \mathrm{ppms}$ \\
\hline \multirow{3}{*}{ SY } & $\mathrm{O}_{3}$ & TE 49C Ozone Analyzer & Ultraviolet photometric method & $0-200 \mathrm{ppmv}$ & $1.0 \mathrm{ppbv}$ \\
\hline & $\mathrm{NO}_{\mathrm{x}}$ & TE 42CTL Analyzer & Chemiluminescence & $0-200 \mathrm{ppbv}$ & $50 \mathrm{pptv}$ \\
\hline & $\mathrm{CO}$ & TE 48C CO Analyzer & Gas filter correlation & $0-10000 \mathrm{ppmv}$ & $0.04 \mathrm{ppms}$ \\
\hline \multirow{3}{*}{ SDZ } & $\mathrm{O}_{3}$ & TE 49C Ozone Analyzer & Ultraviolet photometric method & $0-200 \mathrm{ppmv}$ & $1.0 \mathrm{ppbr}$ \\
\hline & $\mathrm{NO}_{\mathrm{x}}$ & TE 42CTL Analyzer & Chemiluminescence & $0-200 \mathrm{ppbv}$ & $50 \mathrm{pptv}$ \\
\hline & $\mathrm{CO}$ & TE 48C CO Analyzer & Gas filter correlation & $0-10000 \mathrm{ppmv}$ & $0.04 \mathrm{ppms}$ \\
\hline
\end{tabular}

3 , respectively. In general, pollutant mixing ratios at the four monitoring sites had a similar day-to-day variation pattern, in accord with the variation of meteorological parameters. For example, five high-ozone episodes (21-26 June, 4-7 July, 21-27 July, 18-24 August, and 4-12 September) were observed under the similar meteorological conditions with low relative humidity, moderate pressure, high temperature, and high solar radiation. Also, five cooling processes happened clearly in the periods 27 June-3 July, 13-14 July, 30 July-7 August, 26 August, and 13-14 September, respectively. Nearly all these processes began with a decrease in air temperature and solar radiation and an increase in relative humidity, which are generally associated with cold fronts followed by dry and cold air masses. With the change of weather conditions, the mixing ratios of air pollutants changed correspondingly. Generally, when the cooling processes occurred, the pollutant levels decreased dramatically at all sites. When the weather was controlled by stagnant high pressure systems, the pollutants accumulated gradually. The similar day-to-day variations of pollutant mixing ratios at all sites coincided with the meteorological conditions, reflecting a regional-scale character of synoptic system over urban and rural areas of Beijing.

Statistical summary of hourly averaged mixing ratios of $\mathrm{O}_{3}$ and its precursors at each station is given in Table 2. Mean $\mathrm{NO}_{\mathrm{x}}$ mixing ratio observed at the SDZ site was much lower than at the other three sites. As shown in Fig. 3, hourly averaged $\mathrm{NO}_{\mathrm{x}}$ concentrations at SDZ were generally less than $20 \mathrm{ppbv}$, much lower than a rang of 30-100 ppbv observed at other sites. CO mixing ratio observed at SDZ is comparable to, though generally lower than, those observed at other sites (Fig. 3). The peak $\mathrm{CO}$ value was about several ppmv, while the lowest value approached 100-200 ppbv under high speed winds (especially with northerly winds). In contrary, mean $\mathrm{O}_{3}$ mixing ratio at SDZ is much higher than that observed at
Table 2. Statistical summary of hourly averaged concentrations of $\mathrm{O}_{3}$ and its precursors for each station.

\begin{tabular}{|c|c|c|c|c|}
\hline Station & & $\mathrm{O}_{3}$ (ppbv) & $\mathrm{CO}$ (ppbv) & $\mathrm{NO}_{\mathrm{x}}(\mathrm{ppbv})$ \\
\hline \multirow{4}{*}{ FT } & Mean & 36.2 & - & 61.0 \\
\hline & S.D. ${ }^{\mathrm{a}}$ & 34.1 & - & 35.2 \\
\hline & Max Value & 171.2 & - & 243.5 \\
\hline & $\mathrm{N}^{\mathrm{b}}$ & 1994 & - & 2133 \\
\hline \multirow{4}{*}{ BL } & Mean & 47.0 & 1169 & 34.9 \\
\hline & S.D. ${ }^{\mathrm{a}}$ & 41.6 & 763 & 16.8 \\
\hline & Max Value & 274.8 & 4626 & 120.3 \\
\hline & $\mathrm{N}^{\mathrm{b}}$ & 1978 & 2003 & 1891 \\
\hline \multirow{4}{*}{ SY } & Mean & 39.6 & 1792 & 42.9 \\
\hline & S.D. ${ }^{\mathrm{a}}$ & 36.6 & 544 & 29.0 \\
\hline & Max Value & 198.7 & 4855 & 258.0 \\
\hline & $\mathrm{N}^{\mathrm{b}}$ & 2102 & 2136 & 2105 \\
\hline \multirow{4}{*}{ SDZ } & Mean & 58.2 & 910 & 7.9 \\
\hline & S.D. ${ }^{a}$ & 32.1 & 511 & 4.7 \\
\hline & Max Value & 189.3 & 2500 & 30.4 \\
\hline & $\mathrm{N}^{\mathrm{b}}$ & 2114 & 2045 & 2083 \\
\hline
\end{tabular}

a S.D. represents standard deviation.

${ }^{b} \mathrm{~N}$ represents number of samples.

other sites, due to the effect of weak titration reaction in the rural area with low $\mathrm{NO}_{\mathrm{x}}$ emissions.

Fifty-five NMHCs species, including alkanes, alkenes and aromatic hydrocarbons, were measured. The mean total NMHCs mixing ratio was $149 \mathrm{ppbv}$ at $\mathrm{BL}$, which is 3.6 times as high as that measured at SDZ. The maximum total NMHCs mixing ratio was $232 \mathrm{ppbv}$ at BL, which is much higher than the mixing ratio of $70 \mathrm{ppbv}$ observed at SDZ. We further divide NMHCs into four groups, namely alkanes, alkenes, aromatics, and biogenic VOCs (include isoprene, 


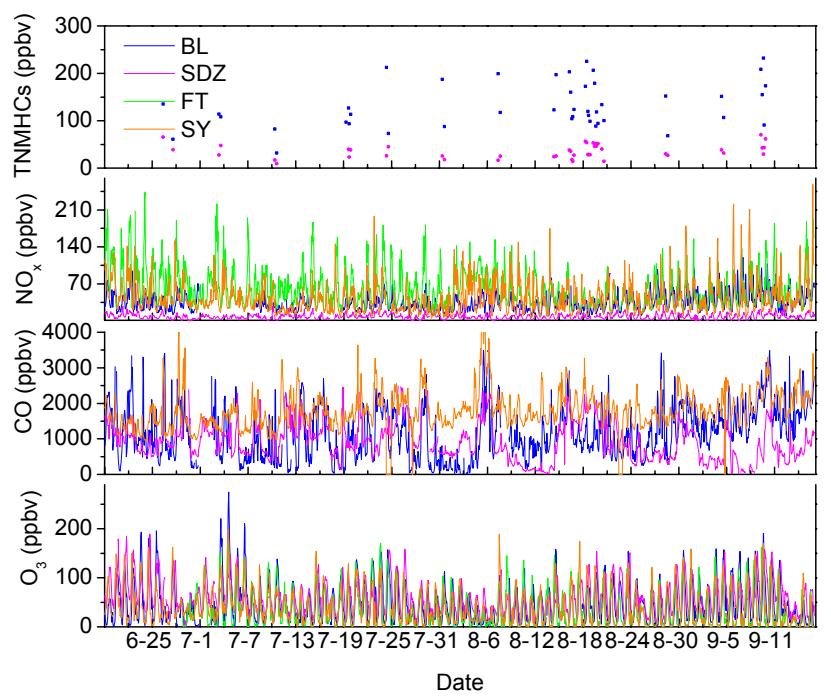

Fig. 3. Time series of hourly averaged TNMHCs, $\mathrm{NO}_{\mathrm{x}}, \mathrm{CO}$ and $\mathrm{O}_{3}$ concentrations at the four sites.

$\alpha$-pinene and $\beta$-pinene), of which the first three groups are mainly emitted from anthropogenic sources. While isoprene was reported to be related to both biogenic and anthropogenic sources in Karachi, Pakistan (Barletta et al., 2005) and Hong Kong, China (So and Wang, 2004), it has been proven that isoprene is mostly biogenic rather than anthropogenic in summer in Beijing (Duan et al., 2008). As shown in Fig. 4, the estimated contributions of each divided group to the total NMHCs are: alkanes $49.1 \%$, alkenes $15.3 \%$, aromatics $32.8 \%$, and biogenic VOCs $2.8 \%$ at BL, and alkanes $47.8 \%$, alkenes $19.0 \%$, aromatics $29.4 \%$, and biogenic VOCs $3.8 \%$ at SDZ, respectively. The mixing ratio and composition of NMHCs at BL (SDZ) are similar to those measured at other urban (rural) site in Beijing as reported by previous studies (Xie et al., 2008; Shao et al., 2009).

\subsection{NMHCs reactivity and ozone formation potential}

The abilities of individual NMHC to influence the ozone formation potential (OFP) can be estimated by using the "Maximum Incremental Reactivity" (MIR) scale in $\mathrm{O}_{3}$ together with measured mixing ratios of NMHCs (Carter, 1994;Derwent et al., 1998; Butler et al., 2011). The average mixing ratios, the reactivity with $\mathrm{OH}\left(L_{\mathrm{OH}}\right)$ and $\mathrm{OFP}$ of all individual NMHCs and CO at BL and SDZ are listed in Table 3. The $\mathrm{OH}$ loss rate coefficient $\left(L_{\mathrm{OH}}\right)$ by total NMHCs at the BL and SDZ sites were $50.7 \mathrm{~s}^{-1}$ and $15.8 \mathrm{~s}^{-1}$, respectively, indicating that the reactivity of NMHCs was much higher in the urban area than in the rural area. Similarly, the OFP of total NMHCs was much stronger $\left(\sim 1380 \mu \mathrm{g} \mathrm{m}^{-3}\right)$ at BL than at SDZ $\left(\sim 320 \mu \mathrm{g} \mathrm{m}^{-3}\right)$. Interestingly, high $L_{\mathrm{OH}}$ and OFP of $\mathrm{CO}$ are estimated, comparable to a substantial fraction of the total NMHCs, especially at the rural site.

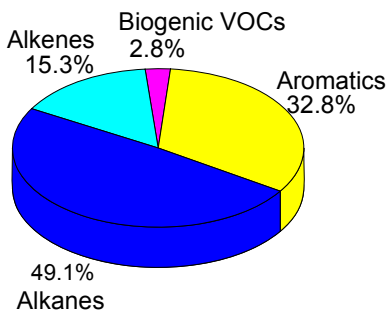

BL

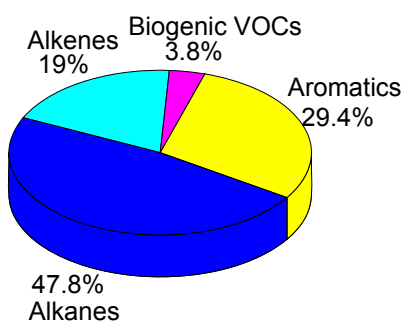

SDZ
Fig. 4. Percentages of alkanes, alkenes, biogenic VOCs and aromatics in NMHCs at BL (left, TNMHCs: 149 ppbv) and SDZ (right, TNMHCs: $41 \mathrm{ppbv})$.

The percentage contributions of alkanes, alkenes, biogenic VOCs, aromatics and carbon monoxide to the total $L_{\mathrm{OH}}$ and OFP are shown in Figs. 5 and 6 respectively. Note that we did not consider methane and oxidation products of NMHCs in the total $L_{\mathrm{OH}}$ and OFP. As shown in Figs. 5 and 6, alkenes made a dominant contribution to the total reactivity $L_{\mathrm{OH}}$ and aromatics dominated OFP at both urban and rural sites. Both biogenic VOCs and carbon monoxide made a greater percentage contribution to $L_{\mathrm{OH}}$ and OFP at the rural site than at the urban site. The top 10 NMHCs with the largest value of $L_{\mathrm{OH}}$ and OFP at each site are shown in Fig. 7, in comparison with $\mathrm{CO}$. With respect to the individual species, $\mathrm{CO}$ had the largest ozone formation potential at the rural site, followed by 1,3,5-trimethybenzene, $m, p$-xylene and isoprene. At the urban site aromatic species, i.e. $m, p$-xylene, toluene and 1,2,4-trimethybenzene, were the leading contributors, though the contribution from $\mathrm{CO}$ was also considerable. These indicate that the long lifetime species like $\mathrm{CO}$ could be transported to the downwind area and affect the ozone formation at the rural site.

Besides, it should be noted whereas the concentration of biogenic VOCs was smaller in the rural area (1.59 ppbv) than that in the urban area $(4.18 \mathrm{ppbv})$, the percentage contribution of biogenic VOCs to both total $L_{\mathrm{OH}}$ and OFP was obviously higher at the rural site. Our data analysis shows that isoprene has a negative and poor correlation with $\mathrm{CO}$ but a good correlation with temperature. This means that isoprene is mostly biogenic rather than anthropogenic in summer in Beijing. Deciduous trees, which are often used to decorate the urban roads, and holly coniferous trees, which are common in most of the urban parks, can release substantial amounts of isoprene and monoterpenes into urban atmosphere in Beijing, respectively (Wang et al., 2003). The SDZ site is surrounded mainly by crops and fruit trees with much less emissions of isoprene and monoterpenes. Therefore, higher biogenic VOCs were observed at BL than at SDZ. On the other hand, since anthropogenic VOCs are also much lower in the rural area, the relative contributions of biogenic VOCs to the ozone formation are still greater at SDZ than at BL. It should also be noted that biogenic VOCs and some 
Table 3. Chemical characteristics of NMHCs and CO at the BL and SDZ sites.

\begin{tabular}{|c|c|c|c|c|c|c|c|c|}
\hline & \multirow{2}{*}{$10^{12} \times k_{\mathrm{OH}}^{\mathrm{a}}$} & \multirow{2}{*}{$\mathrm{MIR}^{\mathrm{b}}$} & \multicolumn{3}{|c|}{$\mathrm{BL}$} & \multicolumn{3}{|c|}{ SDZ } \\
\hline & & & Mix ratio $^{c}$ & $L_{\mathrm{OH}}^{\mathrm{d}}$ & $\mathrm{OFP}^{\mathrm{e}}$ & Mix ratio ${ }^{c}$ & $L_{\mathrm{OH}}^{\mathrm{d}}$ & $\mathrm{OFP}^{\mathrm{e}}$ \\
\hline ethane & 0.26 & 0.25 & 2.18 & 0.01 & 0.67 & 1.16 & 0.01 & 0.36 \\
\hline ethylene & 8.52 & 7.4 & 1.69 & 0.35 & 14.32 & 0.87 & 0.18 & 7.37 \\
\hline propane & 1.15 & 0.48 & 11.15 & 0.32 & 9.63 & 3.53 & 0.10 & 3.05 \\
\hline propylene & 26.3 & 9.4 & 7.51 & 4.86 & 121.27 & 1.55 & 1.00 & 25.03 \\
\hline isobutane & 2.12 & 1.21 & 8.62 & 0.45 & 23.89 & 2.27 & 0.12 & 6.29 \\
\hline$n$-butane & 2.54 & 1.02 & 1.46 & 0.09 & 3.53 & 1.31 & 0.08 & 3.17 \\
\hline acetylene & 0.83 & - & 1.05 & 0.02 & - & 0.72 & 0.01 & - \\
\hline trans-2-butene & 64 & 10 & 1.26 & 1.98 & 28.86 & 0.20 & 0.31 & 4.58 \\
\hline isobutene & 51.4 & 5.3 & 1.56 & 1.97 & 18.94 & 0.40 & 0.51 & 4.86 \\
\hline 1-butene & 31.4 & - & 2.13 & 1.65 & - & 0.95 & 0.73 & - \\
\hline cis-2-butene & 56.4 & 10 & 0.96 & 1.33 & 21.99 & 0.23 & 0.32 & 5.27 \\
\hline cyclopentane & 5.16 & 2.4 & 0.64 & 0.08 & 4.40 & 0.22 & 0.03 & 1.51 \\
\hline isopentane & 3.6 & 1.38 & 13.36 & 1.18 & 54.29 & 2.79 & 0.25 & 11.34 \\
\hline$n$-pentane & 3.94 & 1.04 & 6.24 & 0.60 & 19.11 & 1.60 & 0.16 & 4.90 \\
\hline 2-methyl-2-butene & 68.9 & 6.4 & 0.36 & 0.61 & 5.28 & 0.15 & 0.25 & 2.20 \\
\hline cyclopentene & 67 & - & 0.28 & 0.46 & - & 0.38 & 0.63 & - \\
\hline trans-2-pentene & 67 & 8.8 & 0.39 & 0.64 & 9.83 & 0.08 & 0.13 & 2.02 \\
\hline 3-methyl-1-butene & 31.8 & 6.2 & 0.55 & 0.43 & 7.81 & 0.10 & 0.08 & 1.42 \\
\hline 1-pentene & 31.4 & 6.2 & 0.65 & 0.50 & 11.54 & 0.28 & 0.22 & 4.97 \\
\hline cis-2-pentene & 65 & 8.8 & 0.75 & 1.20 & 18.90 & 0.18 & 0.29 & 4.53 \\
\hline 2,2-dimethylbutane & 2.23 & 0.82 & 1.53 & 0.08 & 4.41 & 1.41 & 0.08 & 4.07 \\
\hline 2,3-dimethylbutane & 6.3 & 1.07 & 1.50 & 0.23 & 5.65 & 0.69 & 0.11 & 2.60 \\
\hline 2-methylpentane & 5.6 & 1.5 & 4.09 & 0.56 & 21.58 & 0.74 & 0.10 & 3.90 \\
\hline 3-methylpentane & 5.7 & 1.5 & 3.12 & 0.44 & 16.46 & 0.74 & 0.10 & 3.90 \\
\hline isoprene & 101 & 9.1 & 2.25 & 5.59 & 56.95 & 1.13 & 2.81 & 28.60 \\
\hline 4-methyl-1-pentene & - & - & 0.29 & - & - & 0.12 & 0.00 & - \\
\hline 2-methyl-1-pentene & 68.9 & - & 0.34 & 0.58 & - & 0.19 & 0.32 & - \\
\hline$n$-hexane & 5.61 & 0.98 & 4.35 & 0.60 & 14.99 & 0.57 & 0.08 & 1.96 \\
\hline trans-2-hexene & 62.6 & - & 0.99 & 1.52 & - & 0.57 & 0.88 & - \\
\hline cis-2-hexene & 62.7 & - & 2.02 & 3.12 & - & 0.98 & 1.51 & - \\
\hline methylcyclopentane & 7.05 & 2.8 & 2.81 & 0.49 & 27.03 & 0.40 & 0.07 & 3.85 \\
\hline benzene & 1.23 & 0.42 & 11.12 & 0.34 & 14.90 & 4.36 & 0.13 & 5.84 \\
\hline cyclohexane & 7.49 & 1.28 & 1.41 & 0.26 & 6.20 & 0.25 & 0.05 & 1.10 \\
\hline 2-methylhexane & 7.18 & 1.08 & 1.27 & 0.22 & 6.40 & 0.21 & 0.04 & 1.06 \\
\hline 2,3-dimethylpentane & - & - & 0.97 & - & - & 0.31 & 0.00 & - \\
\hline 3-methylhexane & 7.18 & 1.4 & 1.61 & 0.28 & 9.22 & 0.30 & 0.05 & 1.72 \\
\hline 2,2,4-trimethylpentane & 3.34 & 0.93 & 0.53 & 0.04 & 2.30 & 0.14 & 0.01 & 0.61 \\
\hline$n$-heptane & 7.15 & 0.81 & 1.39 & 0.24 & 4.60 & 0.20 & 0.04 & 0.66 \\
\hline methylcyclohexane & 10.4 & 1.8 & 0.98 & 0.25 & 7.07 & 0.10 & 0.03 & 0.72 \\
\hline 2,3,4-trimethylpentane & 6.6 & 1.6 & 0.20 & 0.03 & 1.49 & 0.07 & 0.01 & 0.52 \\
\hline toluene & 5.96 & 2.7 & 15.12 & 2.22 & 153.61 & 2.63 & 0.39 & 26.72 \\
\hline 2-methylheptane & - & 0.96 & 0.66 & - & 2.95 & 0.19 & 0.00 & 0.85 \\
\hline 3-methylheptane & 8.54 & 0.99 & 0.53 & 0.11 & 2.45 & 0.13 & 0.03 & 0.60 \\
\hline$n$-octane & 8.68 & 0.6 & 1.80 & 0.38 & 5.04 & 0.53 & 0.11 & 1.48 \\
\hline ethylbenzene & 7.1 & 2.7 & 5.06 & 0.88 & 59.23 & 1.03 & 0.18 & 12.06 \\
\hline$m, p$-xylene & 19 & 7.4 & 6.53 & 3.05 & 209.50 & 0.92 & 0.43 & 29.52 \\
\hline styrene & 10 & - & 1.39 & 0.34 & - & 0.58 & 0.14 & - \\
\hline$o$-xylene & 13.7 & 6.5 & 2.75 & 0.93 & 77.50 & 0.37 & 0.12 & 10.43 \\
\hline$n$-nonane & 8.68 & - & 0.88 & 0.19 & - & 0.12 & 0.03 & - \\
\hline isopropybenzene & 6.5 & 2.2 & 0.23 & 0.04 & 2.48 & 0.04 & 0.01 & 0.43 \\
\hline$n$-propybenzene & 6 & 2.1 & 1.69 & 0.25 & 17.42 & 1.07 & 0.16 & 11.03 \\
\hline$\alpha$-pinene & 53.7 & 3.3 & 0.52 & 0.69 & 9.55 & 0.10 & 0.13 & 1.84 \\
\hline 1,3,5-trimethylbenzene & 57.5 & 10.1 & 2.05 & 2.90 & 101.62 & 0.76 & 1.08 & 37.67 \\
\hline$\beta$-pinene & 78.9 & 4.4 & 1.41 & 2.74 & 34.51 & 0.36 & 0.70 & 8.81 \\
\hline 1,2,4-trimethylbenzene & 32.5 & 8.8 & 3.00 & 2.40 & 129.57 & 0.56 & 0.45 & 24.19 \\
\hline Total NMHCs & & & 149.18 & 50.72 & 1378.94 & 41.84 & 15.79 & 319.61 \\
\hline carbon monoxide & 0.24 & 0.054 & 1169 & 6.90 & 72.29 & 910 & 5.37 & 56.28 \\
\hline
\end{tabular}

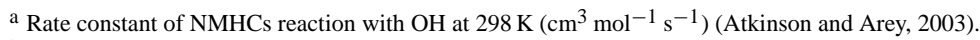

${ }^{\mathrm{b}}$ MIR denotes maximum incremental reactivity ( $\mathrm{g} \mathrm{O}_{3} \mathrm{~g}^{-1}$ VOCs), (Carter, 1994; Ran et al., 2009).

${ }^{c}$ Volumetric mixture ratio, ppbv.

$\mathrm{d}[\mathrm{VOC}] \times k_{\mathrm{OH}}, \mathrm{s}^{-1}$.

e $[\mathrm{VOC}] \times$ MIR, $\mu \mathrm{g} \mathrm{m}^{-3}$. 


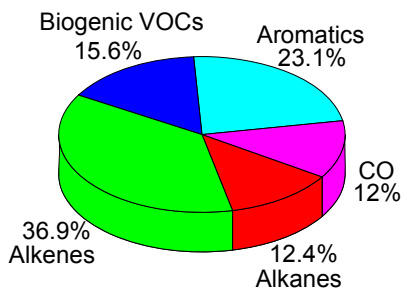

BL

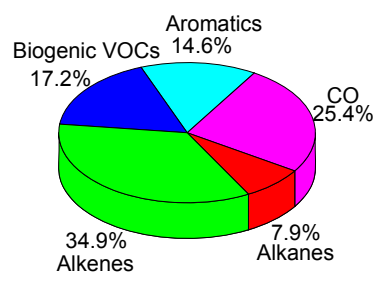

SDZ

Fig. 5. Percentage contributions of alkanes, alkenes, biogenic VOCs, aromatics and carbon monoxide to total $L_{\mathrm{OH}}$ at BL (left, toal $L_{\mathrm{OH}}: 57.6 \mathrm{~s}^{-1}$ ) and SDZ (right, toal $L_{\mathrm{OH}}: 21.2 \mathrm{~s}^{-1}$ ).

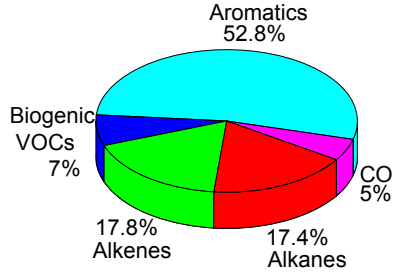

BL

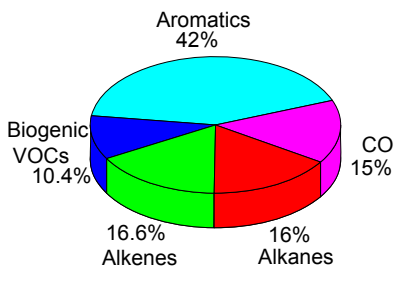

SDZ

Fig. 6. Percentage contributions of alkanes, alkenes, biogenic VOCs, aromatics and carbon monoxide to total OFP at BL (left, total OFP: $1451.2 \mu \mathrm{g} \mathrm{m}^{-3}$ ) and SDZ (right, total OFP: $375.9 \mu \mathrm{g} \mathrm{m}^{-3}$ ).

very reactive aromatic species can be largely consumed after being emitted into air and their chemistry may be very local.

\subsection{Pollutants' diurnal variations and influence of transport}

Daily variations of pollutant concentrations can provide insight into the interplay of emissions and chemical and physical processes that operate on a diurnal cycle. Figure 8 shows the average diurnal variations of $\mathrm{NO}_{\mathrm{x}}$ and $\mathrm{O}_{3}$ at the four measurement sites. The mixing ratios of $\mathrm{NO}_{\mathrm{x}}$ at the FT, BL, and SY sites are comparable and their diurnal variation patterns are similar to each other with two peaks in the morning and early evening. $\mathrm{NO}_{\mathrm{x}}$ measured at SDZ is much lower than at other three sites. Interestingly, there are obvious differences in $\mathrm{O}_{3}$ diurnal pattern at the four sites as indicated by the peak value appearing time. As shown in Fig. 8, the ozone diurnal peak value appears at 13:00, 14:00, 15:00 and 17:00 (Beijing Time) at FT, BL, SY and SDZ, respectively. The ozone peak value time appeared at the upwind site FT is close to and followed by the peak value time (12:00-13:00) of solar radiation, while the ozone peak value time at the downwind site SDZ is much later. Such peak value lagging along the route of prevailing wind from SW to NE can be attributed to the contribution of pollution transport from the up to the down wind area as discussed below.

To investigate the chemical characteristics of air masses from different regions with different histories of atmospheric

processing, it is necessary to segregate the bulk data into groups. We divide the data into three groups based on the diurnal variation of wind directions to look at the effect of transport on pollutant concentrations at the downwind site SDZ. The first group (denoted as Type A) refers to the days when the prevailing wind pattern is characterized by northeasterly at night and turning to southwesterly after sunrise. The second group (denoted as Type B) refers to the days when the prevailing winds are dominated by northwesterly $\left(270^{\circ}-360^{\circ}\right)$ and northeasterly $\left(0^{\circ}-90^{\circ}\right)$. The third group (denoted by Type $\mathrm{C}$ ) refers to the days when the prevailing winds are characterized by southwesterly $\left(180^{\circ}-270^{\circ}\right)$. Considering the location of SDZ, the air mass of Type B has slightly been impacted by anthropogenic emissions and can be assigned as clean air mass, and the air mass of Type $\mathrm{C}$ contains the signature of urban pollution transportation. The difference in the diurnal variation of wind directions between $\mathrm{BL}$ and SDZ is small for each type, indicating that the winds at the two sites were basically affected by the large-scale air flow.

As shown in Fig. 9, the diurnal variation of $\mathrm{O}_{3}$ at $\mathrm{BL}$ is typical for large polluted cities, with minimum values in the early morning, a strong rise during the morning with the increasing solar radiation, peak mixing ratios at about 14:00, and a decline due to ozone destruction by NO during night time (Lal et al., 2000; Duenas et al., 2002; Zhang and Kim, 2002; Ribas and Peuelas, 2004; Mazzeo et al., 2005). While there is no large difference in the diurnal variation of $\mathrm{O}_{3}$ between the three types at BL, different features are found for SDZ. Compared to $\mathrm{BL}$, the $\mathrm{O}_{3}$ peak observed at SDZ was delayed for several hours, with a value being close to that at BL in Type A, much lower in Type B, and higher in Type $C$. These reveal that surface $\mathrm{O}_{3}$ was controlled predominantly by photochemical reaction at $\mathrm{BL}$, and at SDZ it was profoundly affected by the transport of polluted air. According to the definition of Liu (Liu, 1977) "total oxidant" $\left(\mathrm{O}_{\mathrm{x}}=\mathrm{O}_{3}+\mathrm{NO}_{2}\right)$ production is more representative for the real photochemical production than that of ozone. The $\mathrm{O}_{\mathrm{x}}$ mixing ratio observed at SDZ is lower for Type $\mathrm{A}$ in the late morning and early afternoon and much lower for Type B in the daytime and evening. Interestingly, for Type $C$ in the late afternoon and evening, both $\mathrm{O}_{3}$ and $\mathrm{O}_{x}$ mixing ratio are higher at SDZ than at BL. High concentrations of $\mathrm{O}_{3}$ at the rural site can come from two processes. One is in situ photochemical production, and the other is transport from the urban area. CO at SDZ is obviously lower in Type B and higher in Type $\mathrm{C}$ corresponding to the clean and polluted air masses, respectively. Since $\mathrm{O}_{\mathrm{x}}$ at SDZ is also higher, higher $\mathrm{O}_{3}$ at SDZ cannot be explained fully with its weaker titration by NO than at BL. It is indicated that the upwind urban area influences the downwind rural area through the transport of not only $\mathrm{O}_{3}$ itself but also its precursors. The latter tend to result in more net production of $\mathrm{O}_{3}$ when being mixed with background atmosphere in the rural area. Strong influence of urban plumes from Beijing on air quality in the rural area 

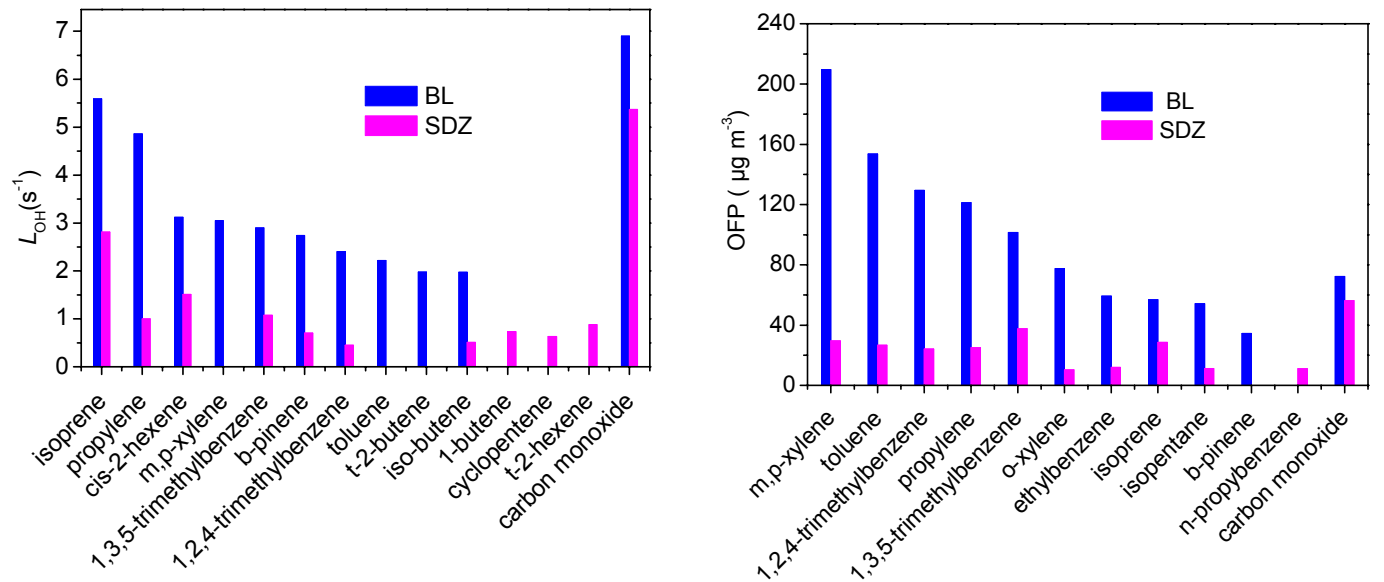

Fig. 7. The $\mathrm{CO}$ and top $10 \mathrm{NMHCs}$ with the largest value of $\mathrm{OH}$ loss rate coefficient $\left(L_{\mathrm{OH}}\right)$ (left) and ozone potential formation $(\mathrm{OFP})$ (right) at BL and SDZ.
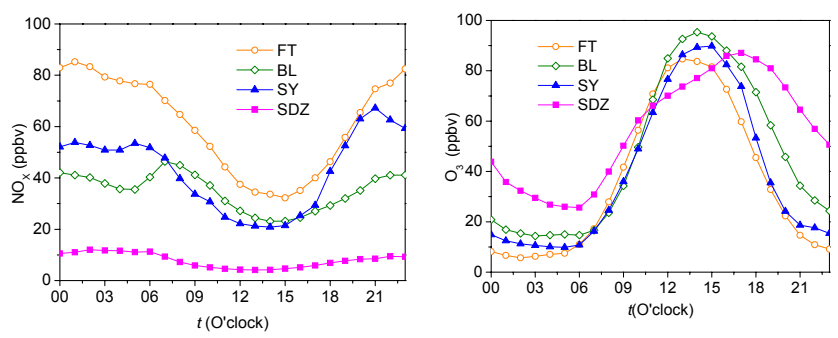

Fig. 8. Average diurnal variations of $\mathrm{NO}_{\mathrm{x}}$ and $\mathrm{O}_{3}$ concentrations observed at the four sites (Beijing time).

has also been observed in previous studies (Wang et al., 2006; Lin et al., 2008). Note that such ozone peak lagging was observed at another downwind rural site in Beijing during the 2008 Olympics as reported by Wang et al. (2010). In contrary to this study, however, they also showed a lagged ozone peak at the upwind rural site in relative to the urban site. It is indicated that in addition to the transport, local photochemistry plays an important role in the diurnal variation of ozone at urban and rural areas.

\subsection{Interspecies correlations and chemical aging of air masses}

\subsubsection{Correlation of $\mathrm{O}_{3}$ and $\mathrm{CO}$}

$\mathrm{CO}$ can be considered as an air pollution transport indicator due to its lifetime of approximately 1 month in the summer. By examining the correlation between $\mathrm{O}_{3}$ and $\mathrm{CO}$, the atmospheric processes of air masses arriving at a monitoring site can be detected. During entire measurement period, the correlation coefficients between $\mathrm{O}_{3}$ and $\mathrm{CO}$ measured at $\mathrm{BL}$ and SDZ are -0.06 and 0.2 , respectively. Poor correlations imply that the concentrations measured at the two sites were affected by complicated processes. Figure 10 shows scatter plots of $\mathrm{O}_{3}$ and $\mathrm{CO}$ for photochemical active afternoon hours (13:00-18:00) observed at the two sites. A moderately good positive correlation $(r=0.52)$ is presented for SDZ with a slope of 0.04 , while there is either a lack of correlation or a weak slope for BL. This phenomenon also appeared in the aged air mass flow from marine and the fresh air mass flow from continent in Hong Kong (Wang et al., 2003). As shown in Fig. 1, the prevailing wind direction was southwest in the afternoon, bringing air masses from the urban to the rural area. Thus, the moderately good positive $\mathrm{O}_{3}-\mathrm{CO}$ correlation observed at the downwind site SDZ can be attributed to the transport of air masses loading large amount of anthropogenic emissions and experiencing strong photochemical processing.

\subsubsection{Correlation of NMHCs species with different lifetimes}

The ratios of VOCs with different photochemical lifetimes can be used to examine the atmospheric processes of air masses, including atmospheric transport and photochemical aging (Nelson and Quigley, 1983). Due to different lifetimes of two given VOCs species, their ratio may change during the course of air mass transport. For the ratio of a more reactive VOCs to a less reactive VOCs, a higher ratio value indicates relatively little photochemical processing of an air mass and major impact from local emissions. On the other hand, a lower ratio value is reflective of more aged VOCs mixes and thus presumably that the VOCs were emitted from longer distant sources. Comparisons of the ratios at different sites can be used to estimate the relative ages of air parcels and help to provide the evidence of transport histories. Moreover, this ratio analysis can further indicate whether the site is dominantly affected by pollutants from local or regional 


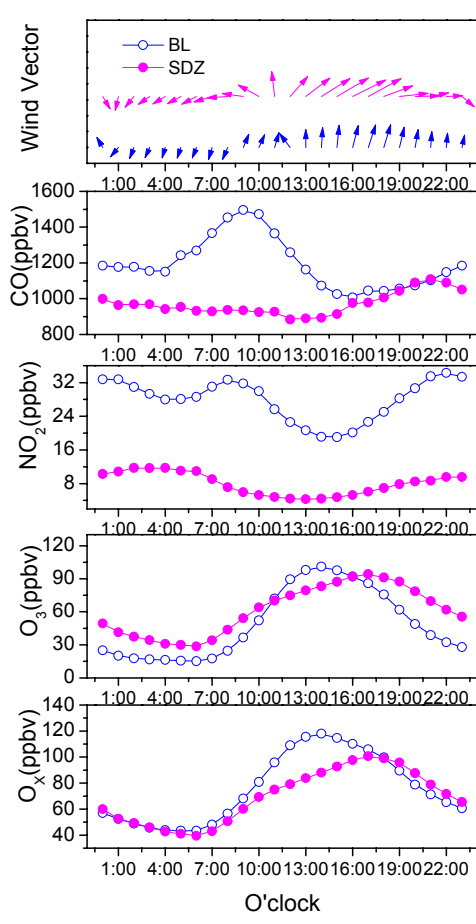

(a)
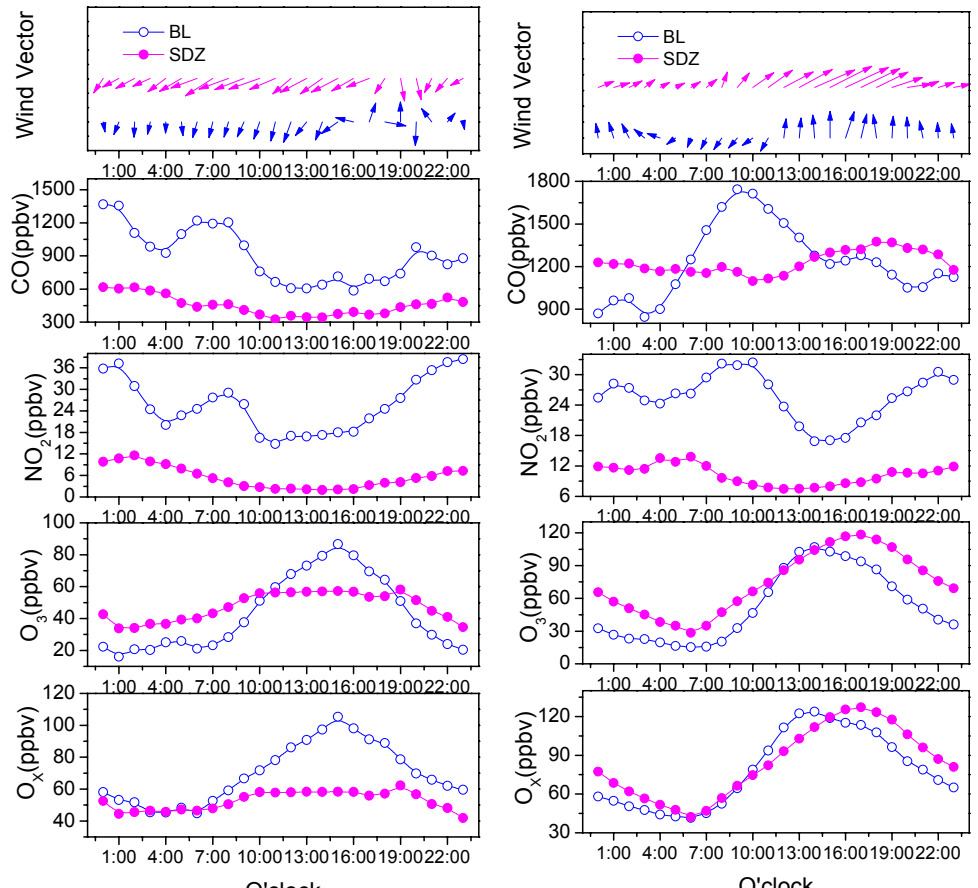

(b)
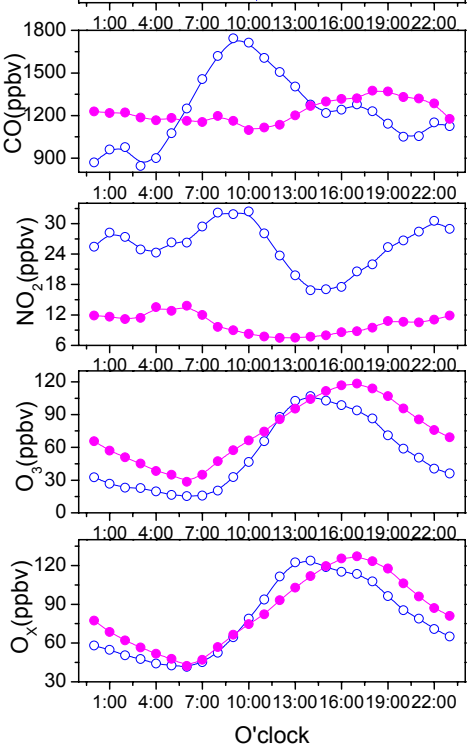

(c)

Fig. 9. Diurnal variation of wind vectors and $\mathrm{CO}, \mathrm{NO}_{2}, \mathrm{O}_{3}$, and $\mathrm{O}_{\mathrm{x}}$ concentrations at the $\mathrm{BL}$ and SDZ sites for the three groups: (a) Type A, (b) Type B, and (c) Type C.

sources. In the analysis presented here, we use the ratios of $m, p$-xylene-to-ethylbenzene and $i$-butane-to-propane at the two sites as a metric of atmospheric processing in different air masses (So and Wang, 2004; Guo et al., 2007; Zhang et al., 2008a). $M, p$-xylene is more reactive than ethylbenzene, with lifetimes about 1 and 2 days, respectively; isobutane also has a shorter lifetime than propane, with lifetimes of about 6 and 12 days, respectively. Figure 11 shows the scatter plots of $m, p$-xylene to ethylbenzene and isobutane to propane at the BL and SDZ sites. Clearly, BL has higher slopes than SDZ for both VOCs ratios, with a $m, p$ xylene-to-ethylbenzene ratio of 1.60 (versus 1.13 at SDZ), and an isobutene-to-propane ratio of 0.71 (versus 0.61 at SDZ). The results suggest that air masses at SDZ were more aged than those at BL, reflecting the importance of regional transport at the SDZ site. The ambient ratios of $m, p$-xyleneto-ethylbenzene at the BL and SDZ sites were lower than those observed in the urban and clean areas of Hongkong (urban, 1.07; clean area, 0.91), respectively; while the ambient ratios of isobutane-to-propane were higher than those observed in Hongkong (urban, 0.38; clean area, 0.26) (Guo et al., 2007). The differences in the regression slopes of these two pairs of recative VOCs at different sites can be caused by both spatial variations in the sources of these species and differences in the photochemical ages of the air masses at these sites (So and Wang, 2004). Vehicle exhaust and the use
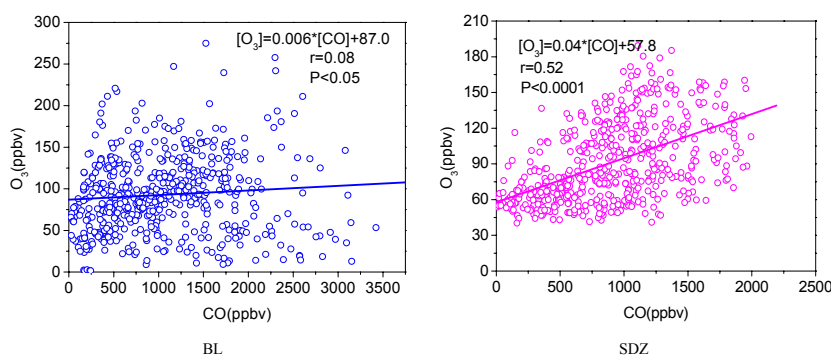

Fig. 10. Scatter plots between $\mathrm{O}_{3}$ and $\mathrm{CO}$ during photochemical active afternoon hours (13:00-18:00) at BL (left) and SDZ (right) sites.

of solvents are the main sources of $m, p$-xylene and ethylbenzene. In contrast, isobutane and propane could be generated from more diverse sources. We found that propane and isobutane have a positive correlation with isoprene (with a correlation coefficient of 0.8 for propane) during daytime at the SDZ site, indicating an important biogenic source of these two VOCs species in rural area. So the ratio of $m, p$ xylene-to-ethylbenzene serves better as an urban plume photochemical indicator in this study. 


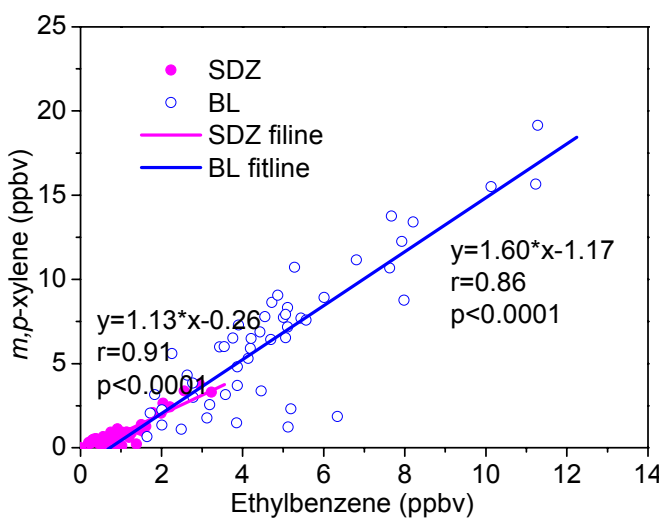

(a)

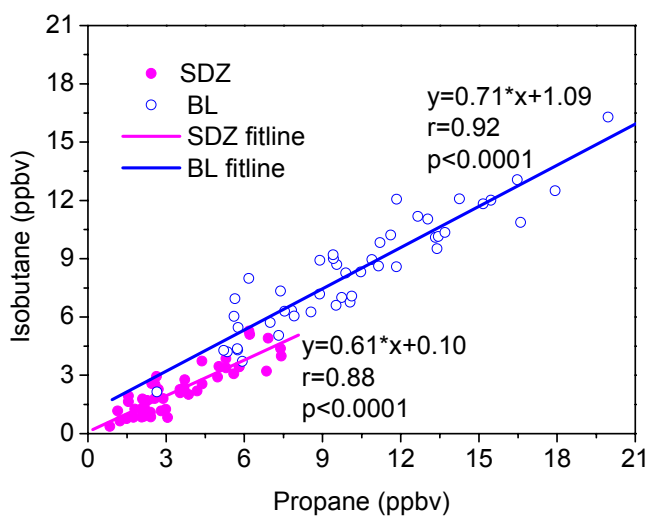

(b)

Fig. 11. Scatter plots of (a) $m, p$-Xylene to ethylbenzene and (b) isobutane to propane at BL and SDZ sites.

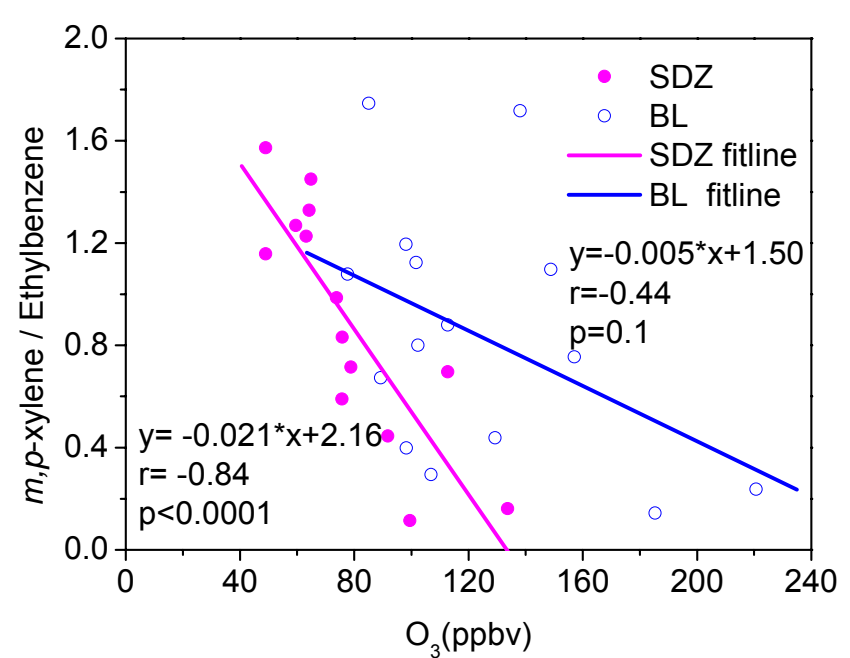

Fig. 12. Scatter plots of $m, p$-Xylene/ethylbenzene ratio to $\mathrm{O}_{3}$ around photochemically active afternoon time (14:00-14:30) at BL and SDZ sites.

\subsubsection{Correlation of $\mathrm{O}_{3}$ with photochemical age}

To further investigate the relationship between observed $\mathrm{O}_{3}$ concentration and photochemical aging degree of air masses at the two monitoring sites, we use the $m, p$ xylenes/ethylbenzene ratio as a metric of photochemical age (Zhang et al., 2008a). As we expected, the $m, p$ xylenes/ethylbenzene ratio and $\mathrm{O}_{3}$ concentration observed during morning time (08:00-08:30) dose not show good correlation at both sites (not shown here). During the hours following sunrise, surface ozone increases due to two factors: local ozone production through conversion of ozone precursors and downward entrainment of ozone from the upper residual layer (Rao et al., 2003). The poor correlation indicates that the entrainment of air from the $\mathrm{O}_{3}$-rich resid- ual layer trapped aloft is important to the accumulation of surface ozone during morning time at both urban and rural sites. Figure 12 shows the relation between the $m, p$ xylenes/ethylbenzene ratio and $\mathrm{O}_{3}$ mixing ratio observed during photochemically active afternoon time (14:00-14:30). At SDZ, higher $\mathrm{O}_{3}$ mixing ratios coincide with greater photochemical age. However, at BL surface ozone seems to be not highly correlated with photochemical age.

\section{Summary and conclusions}

$\mathrm{O}_{3}$ and its precursors were measured at the four sites located along the route of prevailing wind in the Beijing area from June to September 2007. Similar day-to-day variation patterns of pollutants were observed at these sites, indicating that the meteorological conditions in urban and rural areas of Beijing are influenced by regional-scale characteristics of synoptic system. The average levels of reactive gases $\mathrm{NO}_{\mathrm{x}}$ and NMHCs at the downwind rural site SDZ are much lower than those observed at other sites. The level of long-lived gas CO at SDZ is comparable to, though slightly lower than, that at the urban sites. In contrast, due to strong titration by $\mathrm{NO}$, the mean mixing ratios of $\mathrm{O}_{3}$ at the urban site are much lower than that at the rural site.

Measured $\mathrm{CO}$ and NMHCs are used to estimate the photochemical reactivity $\left(L_{\mathrm{OH}}\right)$ and the ozone formation potential (OFP) in the urban (BL) and rural (SDZ) areas of Beijing. It is shown that both the reactivity and ozone formation potential of NMHCs are higher in the urban area than in the rural area. The $\mathrm{OH}$ loss rate coefficient $\left(L_{\mathrm{OH}}\right)$ by total NMHCs at the BL and SDZ sites are estimated to be $50.7 \mathrm{~s}^{-1}$ and $15.8 \mathrm{~s}^{-1}$, respectively. While alkenes make a major contribution to the $L_{\mathrm{OH}}$, aromatics dominate OFP at both urban and rural sites. With respect to the individual species, $\mathrm{CO}$ has the largest ozone formation potential at the rural site, and at the urban site aromatic species are the leading contributors. It 
is indicated that the long lifetime species like CO could be transported to the downwind area and affect the ozone formation at the rural site.

Observed diurnal variation patterns of $\mathrm{NO}_{\mathrm{x}}$ are different between the urban and rural sites due to the effects of both local emissions, e.g. from traffic, and changing meteorological conditions. While the $\mathrm{O}_{3}$ diurnal variations at the four sites are typical for polluted areas in general, the $\mathrm{O}_{3}$ peaks are found to appear at different time, being earlier at the upwind site (e.g. 14:00 LT for BL) and later at the downwind site (e.g. 17:00 LT for SDZ). Such peak value lagging along the route of prevailing wind from SW to NE is attributed to the transport of both $\mathrm{O}_{3}$ and its precursors from the up wind to the down wind area.

Meteorological data analysis shows that the SDZ site is affected by different air mass types, resulting in significant difference in the diurnal variation of $\mathrm{O}_{3}$ observed at SDZ. In the air masses characterized by urban pollution transport, both $\mathrm{O}_{3}$ and $\mathrm{O}_{x}$ are higher at SDZ than at BL. This cannot be fully explained by the weaker $\mathrm{O}_{3}$ titration by $\mathrm{NO}$ at $\mathrm{SDZ}$ than at $\mathrm{BL}$, but indicates more photochemical $\mathrm{O}_{3}$ production when urban plume being mixed with background atmosphere in the rural area. It is shown that observed $\mathrm{O}_{3}$ has a good correlation with $\mathrm{CO}$ as well as polluted air mass age at SDZ. The results demonstrate that urban plume from upwind area loading large amount of pollutants and experienced strong photochemical processing can be transported downwind and contribute greatly to surface ozone in the rural area.

Acknowledgements. This work was supported by NSFC41075111, NSFC40775074, GYHY200806027, and BNSF8082012. The authors would like to thank the staff of the Shangdianzi station for assissting the measurements. We also thank the guest editor, T. Wang, and the two anonymous reviewers for their helpful comments and suggestions on the manuscript.

Edited by: T. Wang

\section{References}

An, J. L.: Ozone production efficiency in Beijing area with high NOx emissions, Acta Scientiae Circumstantiae, 26, 652-657, 2006.

Atkinson, R. and Arey, J.: Atmospheric degradation of volatile organic compounds, Chem. Rev., 103, 4605-4638, 2003.

Barletta, B., Meinardi, S., Sherwood Rowland, F., Chan, C. Y., Wang, X., Zou, S., Yin Chan, L., and Blake, D. R.: Volatile organic compounds in 43 Chinese cities, Atmos. Environ., 39, 5979-5990, 2005.

Butler, T. M., Lawrence, M. G., Taraborrelli, D., and Lelieveld, J.: Multi-day ozone production potential of volatile organic compounds calculated with a tagging approach, Atmos. Environ., 45, 4082-4090, 2011.

Carter, W. P. L.: Development of ozone reactivity scales for volatile organic compounds, J. Air Waste Manage. Assoc., 44, 881-889, 1994.
Chan, C. Y., Chan, L. Y., Cui, H., Zheng, X. D., Zheng, Y. G., Qin, Y., and Li, Y. S.: Origin of the springtime tropospheric ozone maximum over east China at LinAn in 2001, TELLUS 55B, 55, 982-992, 2003.

Cheung, V. T. F. and Wang, T.: Observational study of ozone pollution at a rural site in the Yangtze Delta of China, Atmos. Environ., 35, 4947-4958, 2001.

Chou, C. C. K., Tsai, C. Y., Shiu, C. J., Liu, S. C., and Zhu, T.: Measurement of $\mathrm{NO}_{y}$ during Campaign of Air Quality Research in Beijing 2006 (CAREBeijing-2006): Implications for the ozone production efficiency of $\mathrm{NO}_{\mathrm{x}}$, J. Geophys. Res., 114, D00G01, doi:10.1029/2008JD010446, 2009.

Derwent, R. G., Jenkin, M. E., Saunders, S. M., and Pilling, M. J.: Photochemical ozone creation potentials for organic compounds in northwest Europe calculated with a master chemical mechanism, Atmos. Environ, 32, 2429-2441, 1998.

Ding, A., Wang, T., Zhao, M., Wang, T., and Li, Z.: Simulation of sea-land breezes and a discussion of their implications on the transport of air pollution during a multi-day ozone episode in the Pearl River Delta of China, Atmos. Environ., 38, 6737-6750, 2004.

Duan, J., Tan, J., Yang, L., Wu, S., and Hao, J.: Concentration, sources and ozone formation potential of volatile organic compounds (VOCs) during ozone episode in Beijing, Atmos. Res., 88, 25-35, 2008.

Duenas, C., Fernández, M. C., Caete, S., Carretero, J., and Liger, E.: Assessment of ozone variations and meteorological effects in an urban area in the Mediterranean Coast, The Science of the Total Environment, 299, 97-113, 2002.

Geng, F., Zhao, C., Tang, X., Lu, G., and Tie, X.: Analysis of ozone and VOCs measured in Shanghai: A case study, Atmos. Environ., 41, 989-1001, 2007.

Guo, H., So, K. L., Simpson, I. J., Barletta, B., Meinardi, S., and Blake, D. R.: C1-C8 volatile organic compounds in the atmosphere of Hong Kong: Overview of atmospheric processing and source apportionment, Atmos. Environ., 41, 1456-1472, 2007.

Hao, J. and Wang, L.: Improving urban air quality in China: Beijing case study, J. Air Waste Manage. Assoc., 55, 1298-1305, 2005.

Lal, S., Naja, M., and Subbaraya, B. H.: Seasonal variations in surface ozone and its precursors over an urban site in India, Atmos. Environ., 34, 2713-2724, 2000.

Lam, K. S., Wang, T. J., Wu, C. L., and Li, Y. S.: Study on an ozone episode in hot season in Hong Kong and transboundary air pollution over Pearl River Delta region of China, Atmos. Environ., 39, 1967-1977, 2005.

Lin, W., Xu, X., Zhang, X., and Tang, J.: Contributions of pollutants from North China Plain to surface ozone at the Shangdianzi GAW Station, Atmos. Chem. Phys., 8, 5889-5898, doi:10.5194/acp-8-5889-2008, 2008.

Liu, S. C.: Possible effects on fropospheric $\mathrm{O}_{3}$ and $\mathrm{OH}$ due to $\mathrm{No}$ emissions, Geophys. Res. Lett., 4, 325-328, 1977.

Lu, K. D., Zhang, Y. H., Su, H., Brauers, T., Chou, C. C., Hofzumahaus, A., Liu, S. C., Kita, K., Kondo, Y., Shao, M., Wahner, A., Wang, J. L., Wang, X. S., and Zhu, T.: Oxidant $\left(\mathrm{O}_{3}+\mathrm{NO}_{2}\right)$ production processes and formation regimesin Beijing, J. Geophys. Res., 115, D07303, doi:10.1029/2009JD012714,, 2010.

Mazzeo, N. A., Venegas, L. E., and Choren, H.: Analysis of NO, $\mathrm{NO}_{2}, \mathrm{O}_{3}$ and $\mathrm{NO}_{\mathrm{x}}$ concentrations measured at a green area of Buenos Aires City during wintertime, Atmos. Environ., 39, 
3055-3068, 2005.

Meng, Z. Y., Xu, X. B., Yan, P., Ding, G. A., Tang, J., Lin, W. L., Xu, X. D., and Wang, S. F.: Characteristics of trace gaseous pollutants at a regional background station in Northern China, Atmos. Chem. Phys., 9, 927-936, doi:10.5194/acp-9-927-2009, 2009.

Nelson, P. F. and Quigley, S. M.: The $m, p$-xylenes: ethylbenzene ratio. A technique for estimating hydrocarbon age in ambient atmospheres, Atmos. Environ., 17, 659-662, 1983.

Ran, L., Zhao, C., Geng, F., Tie, X., Tang, X., Peng, L., Zhou, G., Yu, Q., Xu, J., and Guenther, A.: Ozone photochemical production in urban Shanghai, China: Analysis based on ground level observations, J. Geophys. Res., 114, D15301, doi:15310.11029/12008JD010752, 2009.

Rao, S. T., Ku, J. Y., Berman, S., Zhang, K., and Mao, H.: Summertime characteristics of the atmospheric boundary layer and relationships to ozone levels over the Eastern United States, Pure Appl. Geophys., 160, 21-55, 2003.

Ribas, Â. and Pe uelas, J.: Temporal patterns of surface ozone levels in different habitats of the North Western Mediterranean basin, Atmos. Environ., 38, 985-992, 2004.

Shao, M., Tang, X., Zhang, Y., and Li, W.: City clusters in China: air and surface water pollution, Front. Ecol. Environ., 4, 353$361,2006$.

Shao, M., Lu, S., Liu, Y., Xie, X., Chang, C., Huang, S., and Chen, Z.: Volatile organic compounds measured in summer in Beijing and their role in ground-level ozone formation, J. Geophys. Res., 114, D00G06, doi:10.1029/2008JD010863, 2009.

So, K. L. and Wang, T.: On the local and regional influence on ground-level ozone concentrations in Hong Kong, Environ. Pollut., 123, 307-317, 2003.

So, K. L. and Wang, T.: $\mathrm{C}_{3}-\mathrm{C}_{12}$ non-methane hydrocarbons in subtropical Hong Kong: spatial-temporal variations, source-receptor relationships and photochemical reactivity, Sci. Total Environ., 328, 161-174, 2004.

Tang, J., Wang, M., Cheng H., Ding, G., Yu, X., Zhou, H., and Liu, G.: Variation characteristics of ambient NMHCs at Shangdianzi and Lin'an Regional GAW sites, Acta Meteorol. Sin., 21, 334$341,2007$.

Tang, G., Li, X., Wang, Y., Xin, J., and Ren, X.: Surface ozone trend details and interpretations in Beijing, 2001-2006, Atmos. Chem. Phys., 9, 8813-8823, doi:10.5194/acp-9-8813-2009, 2009.

Tang, X., Wang, Z., Zhu, J., Gbaguidi, A. E., Wu, Q. Z., Li, J., and Zhu, T.: Sensitivity of ozone to precursor emissions in urban Beijing with a Monte Carlo scheme, Atmos. Environ., 44, 38333842,2010

Wang, B., Shao, M., Lu, S. H., Yuan, B., Zhao, Y., Wang, M., Zhang, S. Q., and Wu, D.: Variation of ambient non-methane hydrocarbons in Beijing city in summer 2008, Atmos. Chem. Phys., 10, 5911-5923, doi:10.5194/acp-10-5911-2010, 2010.
Wang, M. L., Cheng, H. B., Meng, Z. Y., and Ding, G. A.: Determination of Volatile Hydrocarbon in Atmosphere by TwoDimensional Capillary Column Gas Chromatography, Chinese Journal of Chromatography, 20, 172-177, 2002.

Wang, T., Ding, A. J., Blake, D. R., Zahorowski, W., Poon, C. N., and Li, Y. S.: Chemical characterization of the boundary layer outflow of air pollution to Hong Kong during February-April 2001, J. Geophys. Res., 108, 8787, doi:10.1029/2002JD003272, 2003.

Wang, T., Nie, W., Gao, J., Xue, L. K., Gao, X. M., Wang, X. F., Qiu, J., Poon, C. N., Meinardi, S., Blake, D., Wang, S. L., Ding, A. J., Chai, F. H., Zhang, Q. Z., and Wang, W. X.: Air quality during the 2008 Beijing Olympics: secondary pollutants and regional impact, Atmos. Chem. Phys., 10, 7603-7615, doi:10.5194/acp-10-7603-2010, 2010.

Wang, T. and Kwok, J. Y. H.: Measurement and analysis of a multiday photochemical smog episode in the Pearl River delta of China, J. App. Meteorol., 42, 404-416, 2003.

Wang, T., Ding, A., Gao, J., and Wu, W. S.: Strong ozone production in urban plumes from Beijing, China, Geophys. Res. Lett., 33, L21806, doi:21810.21029/22006GL027689, 2006.

Wang, Z. H., Zhang, S. Y., Lu, S. H., and Bai, Y. H.: Screenings of 23 plant species in Beijing for volatile organic compound emissions, Enviromental Science, 24, 7-12, 2003.

Xie, X., Shao, M., Liu, Y., Lu, S., Chang, C. C., and Chen, Z. M.: Estimate of initial isoprene contribution to ozone formation potential in Beijing, China, Atmos. Environ., 42, 6000-6010, 2008.

Yuan, Z. B., Lau, A. K. H., Shao, M., and Louie, P. K. K.: Source analysis of volatile organic compounds by positive matrix factorization in urban and rural environments in Beijing, J. Geophys. Res., 114, D00G15, doi:10.1029/2008JD011190, 2009.

Zhang, B. N. and Kim Oanh, N. T.: Photochemical smog pollution in the Bangkok Metropolitan Region of Thailand in relation to $\mathrm{O}_{3}$ precursor concentrations and meteorological conditions, Atmos. Environ., 36, 4211-4222, 2002.

Zhang, J., Wang, T., Chameides, W. L., Cardelino, C., Blake, D. R., and Streets, D. G.: Source characteristics of volatile organic compounds during high ozone episodes in Hong Kong, Southern China, Atmos. Chem. Phys., 8, 4983-4996, doi:10.5194/acp-84983-2008, 2008.

Zhang, Y. H., Su, H., Zhong, L. J., Cheng, Y. F., Zeng, L. M., Wang, X. S., Xiang, Y. R., Wang, J. L., Gao, D. F., and Shao, M.: Regional ozone pollution and observation-based approach for analyzing ozone-precursor relationship during the PRIDE-PRD2004 campaign, Atmos. Environ., 42, 6203-6218, 2008 b.

Zhao, B., Wang, P., Ma, J. Z., Zhu, S., Pozzer, A., and Li, W.: A high-resolution emission inventory of primary pollutants for the Huabei region, China, Atmos. Chem. Phys. Discuss., 11, 20331 20374, doi:10.5194/acpd-11-20331-2011, 2011. 